\title{
Clinical Observations Test
}

National Cancer Institute

\section{Source}

National Cancer Institute. Clinical Observations Test. NCI Thesaurus. Code C119814.

A character or string that represents the long name of the clinical observation assessment. 